\title{
ATTAINDER AND AMENDMENT 2: ROMER'S RIGHTNESS
}

\begin{abstract}
Akhil Reed Amar*
[T]he principle underlying the Court's opinion is that one who is accorded equal treatment under the laws, but cannot as readily as others obtain preferential treatment under the laws, has been denied equal protection of the laws. If merely stating this alleged "equal protection" violation does not suffice to refute it, our constitutional jurisprudence has achieved terminal silliness.
\end{abstract}

- Justice Antonin Scalia, dissenting in Romer v. Evans ${ }^{1}$

Call me silly. In fact, call me terminally silly. For despite Justice Scalia's remarkably confident claim, I believe, and shall try to prove below, that the Romer Court majority opinion invalidating Colorado's Amendment 2 was right both in form and in substance, both logically and sociologically. I stress "form" and "logic" at the outset because I share Justice Scalia's belief in the importance of these things in constitutional adjudication. I also share his commitment to constitutional text, history, and structure, and his suspicion of "free-form" constitutionalism. ${ }^{2}$ And so I shall highlight the text, history, and spirit of a constitutional clause that - though not explicitly invoked by the Romer majority - clarifies and supports the majority's theory: the Article I, section 10 Attainder Clause. ${ }^{3}$ My claim is not that the Equal Protection Clause, relied upon by the Romer Court, was incapable of doing the work; but that the sociology and principles underlying the Attainder Clause

* Southmayd Professor, Yale Law School. B.A. 1980, J.D. 1984, Yale. - Ed. I thank Bruce Ackerman, Vik Amar, Jack Balkin, Guido Calabresi, Steve Calabresi, Owen Fiss, Joe Goldstein, Leslie Hakala, Erez Kalir, Neal Katyal, Renée Lettow, Sandy Levinson, Burke Marshall, Larry Tribe, Evan Wolfson, and Kenji Yoshino for their helpful comments.

1. 116 S. Ct. 1620, 1630 (1996) (Scalia, J., dissenting).

2. Cf. Laurence H. Tribe, Taking Text and Structure Seriously: Reflections on FreeForm Method in Constitutional Interpretation, 108 HARV. L. REV. 1221 (1995). In this article Professor Tribe suggests that in some of my work, I have succumbed to a "freeform method" of constitutional interpretation. Id. at $1225 \mathrm{n} .9,1240,1246-48,1289-92$. I plead not guilty.

3. "No State shall ... pass any Bill of Attainder ...." U.S. ConST. art. I, $\S 10$, cl. 1. A similar provision binds the federal government. See U.S. CoNST. art. I, $\$ 9$, cl. 3. 
powerfully illuminate the facts of Romer, the opinions in Romer, and the spirit of the Equal Protection Clause itself. ${ }^{4}$

I.

In Romer, the United States Supreme Court struck down the following words - which had been adopted by a 1992 statewide referendum as an amendment to the Colorado Constitution - as unconstitutional on their face:

No Protected Status Based on Homosexual, Lesbian, or Bisexual Orientation. Neither the State of Colorado, through any of its branches or departments, nor any of its agencies, political subdivisions, municipalities or school districts, shall enact, adopt or enforce any statute, regulation, ordinance or policy whereby homosexual, lesbian or bisexual orientation, conduct, practices or relationships shall constitute or otherwise be the basis of or entitle any person or class of persons to have or claim any minority status, quota preferences, protected status or claim of discrimination. This Section of the Constitution shall be in all respects selfexecuting. ${ }^{5}$

Justice Kennedy wrote for a six-Justice majority. Justice Scalia (joined by Chief Justice Rehnquist and Justice Thomas) let fly a stinging dissent.

Since Romer came down, I have had many conversations about it with law professors and law students across the country. The initial consensus seems to be that while Justice Kennedy's language soared, Justice Scalia's logic held. Justice Kennedy won their hearts; Justice Scalia, their heads.

I must confess that before I read Justice Kennedy's opinion which builds in part on an evocative amicus brief submitted by Laurence Tribe, John Hart Ely, Gerald Gunther, Philip Kurland, and Kathleen Sullivan ${ }^{6}$ - I too had great difficulty in seeing how the Colorado referendum was unconstitutional. I reasoned as follows:

It is hard to see how, under existing equal protection doctrine, a simple declaration that "sexual orientation is not just like race" is unconstitutional. To be sure, a strong argument can be made that sexual orientation discrimination is like - indeed is itself a form of - sex

4. For a superb analysis of Romer that complements the one I shall offer here, see generally Daniel Farber \& Suzanna Sherry, The Pariah Principle, 13 CONST. COMMENTARY (forthcoming 1996).

5. $116 \mathrm{~S}$. Ct. at 1623 (quoting Colo. Const. art. II, § 30b).

6. Brief of Laurence H. Tribe, John Hart Ely, Gerald Gunther, Philip B. Kurland, and Kathleen M. Sullivan as Amici Curiae in Support of Respondents, Romer v. Evans, 116 S. Ct. 1620 (1996) (No. 94-1039) [hereinafter Brief]. Especially important analysis appears id. at 6 n.2. 
discrimination. ${ }^{7}$ But the Supreme Court has yet to see this light; and in any event, it has long treated sex discrimination differently from race discrimination. In doctrinal jargon, race discrimination requires "strict scrutiny" while sex discrimination generates "intermediate scrutiny." And so if the declaration "sex and sexual orientation discrimination are different from race discrimination" is unconstitutional under Supreme Court equal protection doctrine, then the Constitution itself - as construed by the Supreme Court - is unconstitutional. And that idea is silly. Terminally.

Thus, if Colorado's cities had never adopted ordinances requiring courts, in effect, to give strict scrutiny to sexual orientation discrimination, that failure to treat sexual orientation exactly like race would not have been unconstitutional under Supreme Court equal protection doc-

7. True, a ban on, say, gay marriage is applied against both sexes - gay men and lesbian women. But a ban on interracial marriage is likewise applied against both blacks and whites. A ban on interracial marriage requires formal race labeling: if the bride is white, the groom may marry if white, but not if black. And so the government must have Nuremberg-like blood codes to determine if the "octoroon" Homer Plessy is white or black. Similarly, a ban on gay marriage requires formal sex labeling: if the "bride" is a woman, the "groom" may marry if a man, but not if a woman. And here too, "octoroon"-like problems emerge. What if the groom is a cross-dressing transsexual? Or has had (or is planning to have) a sex-change operation? Or is XXY? What if the "bride" is genetically male, but was born with female genitals (as sometimes happens naturally)? So, just as miscegenation laws were not race-blind, sexual orientation laws are not sex-blind. And moving beyond form to substance, the social meaning of miscegenation laws was the legal enactment of racial hierarchy - trying to create the social and biological illusion of separate races (which cannot interbreed) rather than a single human race (which can intrabreed): real whites stick with their own kind. So too, the social meaning of sexual orientation discrimination is the legal enactment of chauvinism: real men sleep with real women. Heterosexism is a form of sexism that perpetuates traditional gender roles and chauvinism just as miscegenation laws were a form of racism that perpetuated traditional race roles and white supremacy.

These ideas are developed in more detail in Andrew Koppelman, Note, The Miscegenation Analogy: Sodomy Laws as Sex Discrimination, 98 YALE L.J. 145 (1988) and Andrew Koppelman, Why Discrimination Against Lesbians and Gay Men Is Sex Discrimination, 69 N.Y.U. L. REv. 197 (1994). See also Sylvia Law, Homosexuality and the Social Meaning of Gender, 1988 Wis. L. REV. 187.

8. The Court, however, has recently left the door open to the argument that sex discrimination should perhaps receive strict scrutiny. See, e.g., J.E.B. v. Alabama, 114 S. Ct. 1419, 1425 n.6 (1994). But even if both kinds of discrimination get strict scrutiny, it is hard - at least right now - to think that, say, sex-segregated bathrooms would stand or fall with race-segregated bathrooms.

After its decision in Romer, the Supreme Court seemed to give even more "bite" to intermediate scrutiny in the V.M.I. case, United States v. Virginia, 116 S. Ct. 2264 (1996), but even this case did not treat sex just like race. The Court did not, for example, categorically ban all single-sex state education on the theory that separate is inherently unequal. 
trine. ${ }^{9}$ But surely if Denver, Aspen, and Boulder do enact ordinances treating sexual orientation like race for antidiscrimination purposes, these cities are not forever barred from later repealing these ordinances. Repeal here is a kind of state action, but not an unconstitutional kind. The Constitution does not require that "special" antidiscrimination rights, once extended, irrevocably vest via some magic and antidemocratic one-way ratchet. And if Denver, Aspen, and Boulder can repeal these ordinances, presumably the Colorado legislature can repeal them by statute; and so too the people of Colorado can repeal them by state constitutional amendment (via initiative or referendum). To think otherwise is terminally silly. ${ }^{10}$

To be sure, Colorado's Amendment 2 "entrenches" its No Strict Scrutiny For Sexual Orientation Discrimination Rule in the sense that opponents of the stingy rule can now prevail only by passing a new constitutional amendment rather than a local ordinance or a state statute. Passing a new constitutional amendment is of course an onerous task. But all constitutional provisions entrench in this sense. The Strict Scrutiny For Race Discrimination Rule in the Fourteenth Amendment, as construed by the Supreme Court, itself entrenches in just this way. Opponents of this federal rule can now prevail only by passing a new federal constitutional amendment (rather than a state law or congressional statute). And, of course, it is notoriously tough to pass a new federal constitutional amendment. But surely that entrenchment does not make the Fourteenth Amendment itself unconstitutional. To think it does would be terminally silly.

The Denver, Aspen, and Boulder ordinances repealed by Amendment 2, however, did more than prohibit government from discriminating on the basis of orientation. The ordinances also prohibited certain forms of private discrimination - in employment and in housing, for example. But surely the cities were not constitutionally obliged to pass these private discrimination codes. The federal Constitution generally does not require that the government prohibit private discrimination. If it did, the "state action" requirement of the Equal Protection Clause which bans government discrimination but not private discrimination -

9. Imagine, for example, a city college affirmative action plan for gays. A racebased affirmative action policy would require strict scrutiny; but must sexual orientation be treated just like race here under Court precedents?

10. But cf. Washington v. Seattle Sch. Dist. No. 1, 458 U.S. 457 (1982); Hunter v. Erickson, 393 U.S. 385 (1969); Reitman v. Mulkey, 387 U.S. 369 (1967). On purely formal grounds, these cases are hard to understand. Perhaps the best way to make sense of them is that they frown on the entrenchment of racial segregation and on excessive racial polarization of populist politics; and they reflect suspicion of "gerrymandered" procedural rules treating racial issues differently from other political issues. 
would itself be unconstitutional. And that idea would be - well, you get the point. For the reasons we have already seen, repeal is no different from failure to enact; and neither is repeal by dint of an "entrenching" constitutional amendment.

II.

How did Justice Kennedy's majority opinion deal with all this? Largely by side-stepping it through a more careful reading of Amendment 2 , in a formal and textual analysis that should have commanded the respect, if not the assent, of a principled formalist/textualist like Justice Scalia. Beyond this formal and textual analysis - which paid the Colorado electorate the high compliment of taking their words seriously - Justice Kennedy's opinion showed remarkable sensitivity to the mean purpose and dark social meaning lurking beneath these words.

Amendment 2, Justice Kennedy argued, did not merely declare that sexual orientation is not like race. Strictly speaking, it did not address sexual orientation per se. Rather, it explicitly singled out for disfavored treatment "homosexual, lesbian [and] bisexual orientation." Twice the Amendment used these words, once in its caption. Under Amendment 2 , heterosexuals could win local ordinances and state laws protecting themselves from being discriminated against on the basis of their sexual orientation, but nonheteros could not win symmetric ordinances and laws. This point is not purely theoretical but palpably real. Amendment 2 did not repeal Denver's, Aspen's, and Boulder's ordinances in toto, but only insofar as these ordinances protected homosexuals, lesbians, and bisexuals from orientation discrimination. Under the Boulder Code (as modified by Amendment 2), Boulder was not permitted to discriminate against heteros on the basis of their orientation, but homos and bis were shut out of this Code's sympathetic protection. Under Denver law (as modified by Amendment 2), a gay apartment complex owner was barred from posting a "For Rent - No Straights" sign; but a straight apartment complex owner was free to post a "For Rent - No Queers" sign. Thus, if a plaintiff filed a complaint that defendant fired her because of her sexual orientation, a judge following both state and local law would have been obliged to ask her to amend her complaint by stating her orientation; and if she answered "gay," the judge would have been obliged to rule against her on this ground alone.

Beneath this formal inequality - this exclusion from the law's protections because of who gays are - lurked substantive inequality, Kennedy argued. The Amendment itself, in its social meaning, was a kind of "No Queers" sign writ large. Its caption, "No Protected Status Based on Homosexual, Lesbian, or Bisexual Orientation," came un- 
comfortably close to "No Protect[ion for] Homosexual[s], Lesbian[s] or Bisexual[s]." It was a kind of legal and social outlawry in cowboy country - a targeting of outsiders, a badge of second-class citizenship, a tainting of queers, a scarlet $Q$. The queer (pun intended) language of Amendment 2 - its odd and obsessive singling out of all nonstandard sexual orientations - was a subtle cue, a Freudian slip that old fashioned animus was afoot here. ${ }^{11}$ When a person blurts out the n-word, we wonder; when a voting district looks utterly uncouth in shape, judges are suspicious; ${ }^{12}$ and eyebrows are raised when Colorado voters adopt an amendment that is "unprecedented in our jurisprudence." 13

III.

Though it went unnamed in Justice Kennedy's opinion, the Attainder Clause of Article I, Section 10 helps clarify and illuminate his argument and, as we shall see, offers lawyers litigating gay rights cases a particularly rich and apt source of doctrine. Perhaps the Court omitted explicit mention of this Clause - and hinted at it only en passant because it was not explicitly invoked by the parties (or by any of the many amici).${ }^{14}$ But the Supreme Court may generally affirm a correct disposition below on any ground. (Indeed, as we shall see, Justice Kennedy's opinion explicitly side-stepped the Colorado Supreme Court's basis for invalidating Amendment 2, and thus affirmed on an entirely different theory than the court below.) More important, the Attainder Clause, in its logic and spirit, is an early forebear of the Equal Protection Clause, on which the Court did lean. It is no surprise, then, that plaintiffs in the landmark Bolling $v$. Sharpe $e^{15}$ case - which held that federal actions were subject to equal protection principles - explicitly relied on the Attainder Clause of Article I, Section 9, which speaks specifically to federal action. ${ }^{16}$ Jim Crow laws, plaintiffs argued,

11. Cf. Bowers v. Hardwick, 478 U.S. 186, 200 (1986) (Blackmun, J., dissenting) (criticizing "the Court's almost obsessive focus on homosexual activity" in light of the fact that the Georgia statute at issue nowhere distinguished between homosexual and heterosexual sodomy). (1993).

12. See Gomillion v. Lightfoot, 364 U.S. 339 (1960); Shaw v. Reno, 509 U.S. 630

13. Romer v. Evans, 116 S. Ct. 1620,1628 (1996).

14. The brief submitted by Professor Tribe and others, however, did explicitly invoke the related idea of outlawry, and it pointedly cited pages from a Supreme Court case discussing outlawry and attainder. See Brief, supra note 6, at 10-11 (citing Communist Party v. Subversive Activities Control Bd., 367 U.S. 1, 82, 88 (1961)).

15. 347 U.S. 497 (1954).

16. See Richard Kluger, Simple Justice 522 (1994) (discussing the causes of action pled in the Bolling complaint). 
had the purpose and effect of stigmatizing blacks - not for what they did, but for who they were. And that, plaintiffs argued, was a kind of attainder, a legislatively imposed stain and taint. ${ }^{17}$

To see this more clearly, and to see the implications for Romer, let us proceed through a series of hypotheticals.

Hypothetical One. "The Anti-Amar Law. Akhil Reed Amar shall be drawn, hanged, and quartered. His private parts shall be cut off, his blood shall be deemed corrupted, and his children shall be stripped of their inheritance from him." This is a textbook attainder, historically speaking. ${ }^{18}$ A court may impose a death sentence on a named individual, but a legislature may not. And so this law is obviously unconstitutional.

In part, the nonattainder rule is rooted in narrow ideas of adjudicative due process. Before a person is made to suffer a criminal sanction, he must have his day in court, with individual notice of the charges, an opportunity to be heard in his own defense, the assistance of counsel, the chance to confront opposing witnesses in a proceeding governed by proper rules of evidence and relevance, and so forth. ${ }^{19}$ Legislatures op-

17. For further elaboration of this theory, see Akhil Reed Amar, Constitutional Rights in a Federal System: Rethinking Incorporation and Reverse Incorporation, in Benchmarks: Great Constitutional Controversies in THE SUPREME Court 71, 79-81 (Terry Eastland ed., 1995). See also Tribe, supra note 2, at 1298-99 n.247 (similarly suggesting that the Bolling result could be defended on Attainder Clause grounds, thus avoiding the awkwardness of "reverse incorporation").

On the connection in Anglo-American law between attainder and notions of stain and taint, see 1 OXFORD ENGLISH DiCTIONARY 761 (2d ed. 1989); infra note 41.

18. See United States v. Brown, 381 U.S. 437, 441 (1965); 3 JOSEPH STORY, COMMENTARIES ON THE CONSTITUTION OF THE UNITED STATES $\S 1338$, at 209-10 (Boston, Hilliard, Gray \& Co. 1833); LAURENCE H. TRIBE, AMERICAN ConstituTIONAL LAW $\S 10-4$, at 641-42 (2d ed. 1988). In beginning with the "paradigm case" under the Attainder Clause, I here follow the interpretive approach advocated by Professor Rubenfeld. See Jed Rubenfeld, Reading the Constitution as Spoken, 104 YALE L.J. $1119,1169-73$ (1995).

My Hypothetical, though graphic, accurately represents the obvious fixation on the body and the private parts - the insides - of the real-life attainder victim. The typical, highly ritualized sentence of one attainted of treason in England was as follows:

You are to be drawn upon a hurdle to the place of execution, and there you are to be hanged by the neck, and being alive cut down, and your privy-members to be cut off, and your bowels to be taken out of your belly and there burned, you being alive; and your head to be cut off, and your body to be divided into four quarters, and that your head and quarters be disposed of where his majesty shall think fit.

J.H. Baker, Criminal Courts and Procedure at Common Law 1550-1800, in CRIME IN ENGLAND, 1550-1800, at 15, 42 (J.S. Cockburn ed., 1977).

19. See United States v. Lovett, 328 U.S. 303, 316-18 (1946) (invalidating on Attainder Clause grounds a congressional act that in effect condemned three named persons "without the safeguards of a judicial trial"); Cummings v. Missouri, 71 U.S. (4 Wall.) 277, 323 (1867) ("A bill of attainder is a legislative act which inflicts punish- 
erating in the ordinary legislative mode do not typically abide by these adjudicative procedures, and so trial and sentencing by legislatures are banned. ${ }^{20}$

But the nonattainder rule goes much deeper, tapping into basic principles of separation of powers and equal protection. Even if Congress were willing to give me a hearing before attainting me, the Constitution bars it from acting as a court (outside the strictly circumscribed impeachment process). In general, the legislature must prescribe penalties generally and prospectively, behind a suitably impersonal veil of ignorance: "All persons who do $X$ in the future shall be hanged." Those who seek to avoid the noose are thus given fair warning that they must refrain from conduct $X$. Without the nonattainder principle, the legislature could simply single out its enemies - or the politically unpopular - and condemn them for who they are, or for what they have done in the past and can no longer change. Here we see an obvious link between the nonattainder rule and the related ban on ex post facto laws. Indeed, in both Article I, Section 9, limiting Congress, and Article I, Section 10, limiting states, the Attainder and Ex Post Facto Clauses stand side-by-side. A court independent of the legislature may condemn a named person for what he has done in the past; courts operate retrospectively and specifically in discrete cases and controversies: United States v. Amar. But a court must treat like cases alike and may apply only the general criminal norms previously laid down by statute or custom, rather than whatever criminal rules the judges might prefer were they legislators. By separating the process of penal lawmaking and penal adjudication, the Constitution protects both liberty and equality and promotes the rule of law; the legislature can only prescribe new penal rules for all, and the judiciary can only apply pre-existing penal laws against named individuals. ${ }^{21}$ Both legislation and adjudication must be suitably impersonal. Neither legislators nor judges can punish me simply because they do not like me.

Suppose, however, that the legislature does not itself purport to adjudicate guilt and impose a criminal sentence as a court, but instead

ment without a judicial trial . . . [T]he legislative body ... pronounces upon the guilt of the party, without any of the forms or safeguards of trial . . .."); 3 STORY, supra note 18, at 210-11; TRIBE, supra note 18, at 641, 657-63; Charles $\mathrm{H}$. Wilson, Jr., Comment, The Supreme Court's Bill of Attainder Doctrine: A Need for Clarification, 54 CAL. L. REv. 212, 242-46 (1966).

20. On the applicability of the Attainder Clause to popular referenda, see infra note 59.

21. See generally United States v. Brown, 381 U.S. 437 (1965); Note, The Bounds of Legislative Specification: A Suggested Approach to the Bill of Attainder Clause, 72 YALE L.J. 330 (1962). 
passes a clever variant of the Anti-Amar Law: "It shall henceforth (prospectively) be a (general) crime for anyone to be Akhil Reed Amar, to have his blood type, feelings, fingerprints, and DNA. The courts shall apply this (general) law and accord any defendant the traditional procedural rights of notice, opportunity to be heard, counsel, confrontation, and so forth. Anyone found guilty of this (general) crime in court shall be drawn, hanged, quartered, etc." Obviously, this too is a textbook bill of attainder even though it purports to leave "adjudication" of the "crime" to independent courts. It is an attainder because, despite its dishonest protestations, it fails the requisite test of generality and prospectivity. It makes it a capital crime to be who I am. ${ }^{22}$ Put another way, it wrongly designates criminals rather than crimes. $^{23}$

Hypothetical Two. "The Anti-Amar and Public Stigma Law. Akhil Reed Amar shall be placed in the public stocks for two hours. His private parts shall be painted red. ${ }^{24}$ Passersby may mock, insult, and humiliate him." In England, this was known as a "bill of pains and penalties" because it prescribed lesser punishment than that prescribed in

22. Thomas Wentworth, the Earl of Strafford and one of the most famous attainder victims ever, was beheaded in 1641, simply for being himself. For a gripping account of this iniquity, see Zechariah Chafee, JR., Three Human Rights in the ConstiTUTION OF 1787, at 109-13 (1956).

23. My claim here is not that every attainder must be a law that makes it a crime to be who I am, but that every such law must be an attainder. Later, I shall generalize the principle by suggesting that - whatever else it might also ban - the Attainder Clause frowns on all penal laws based on status or identity.

The Attainder Clause implicates at least five basic constitutional ideals, not all of which are present in every attainder case. First, as we have seen, the Clause implicates rights of individualized adjudicatory process - due process rights of notice and the opportunity to be heard. Second, the Clause affirms separation of powers and rule of law notions of generality, prospectivity, transparency, and impersonality. Third, the Clause anticipates the equal protection idea banning stigmatic penalties imposed on an unpopular person or group based on status, especially when laws reflect revulsion toward impure, corrupt, or degraded bodies or body parts. Fourth, the Clause, when read in light of its history, calls for special sensitivity and judicial skepticism when a legislature singles out political agitators or opposition speakers for disfavored treatment. See Brown, 381 U.S. at 441, 453 (invalidating, on Attainder Clause grounds, a congressional act penalizing the Communist Party by name, and noting that "political group[s] . . were the targets of the overwhelming majority of English and early American bills of attainder"); David Kairys, Note, The Bill of Attainder Clauses and Legislative and Administrative Suppression of "Subversives," 67 COLUM. L. REv. 1490, 1499 (1967); Wilson, supra note 19, at 235-37. Finally, the Clause reflects a libertarian scheme of checks and balances by preventing any single branch of government from unilaterally depriving persons of life, liberty, or property. See Akhil Reed Amar, The Bill of Rights as a Constitution, 100 YALE L.J. 1131, 1194 (1991). In the Hypotheticals that follow, I shall especially pursue the second, third, and fourth strands noted above.

For a superb general treatment of the Attainder Clause from which I have greatly profited, see TRIBE, supra note $18, \S \S 10-4$ to -6 .

24. See supra note 18. 
Hypothetical One. ${ }^{25}$ But American Attainder Clause jurisprudence has long recognized - in an unbroken line of cases stretching back to Chief Justice Marshall's opinion in Fletcher v. Peck - that legislatures may not pass such laws singling out named persons for abuse. ${ }^{26}$

Hypothetical Three. "The Amar Outlawry Law. Akhil Reed Amar is declared an outlaw. He is cast out of the law's protection. He is now a stranger to our laws, an unwelcome outsider. Passersby may treat him as a wild beast and may hunt him for sport and kill him without penalty." Historically, this is a textbook bill of outlawry. To be an outlaw is to be cast out of the protection of law. ${ }^{27}$ And outlawry reminds us that the law protects against private as well as public injuries and assaults. In our jurisprudence, it is obvious that a legislative declaration of outlawry violates the nonattainder principle..$^{28}$

Note how, by merely "targeting" certain individuals, the government can often count on private citizens to pull the trigger. Thus, in 1794 James Madison objected to a congressional resolution that did no more than declare that certain specified persons were involved in an insurrection: "It is in vain to say that this indiscriminate censure is no punishment. If it falls on classes, or individuals, it will be a severe punishment. . . . Is not this proposition, if voted, a vote of attainder?" 29

Hypothetical Four. "The Amar Ineligibility Law. Akhil Reed Amar shall be ineligible to be a government employee or a union leader." The legislatively prescribed disadvantages heaped upon a named person here are obviously less severe than in Hypotheticals One and Three. But if

25. See Brown, 381 U.S. at 441-42 ("The 'bill of pains and penalties' was identical to the bill of attainder, except that it prescribed a penalty short of death, e.g. banishment, deprivation of the right to vote, or exclusion of the designated party's sons from Parliament."); see also 3 STORY, supra note 18, at 209-10; TRIBE, supra note 18, at 641-42.

26. See Brown, 381 U.S. at $447-49$ ("what were known at common law as bills of pains and penalties are outlawed by the Bill of Attainder Clause"); United States v. Lovett, 328 U.S. 303, 315-18 (1946) ("Within the meaning of the Constitution, bills of attainder include bills of pains and penalties.") (quoting Cummins v. Missouri, 71 U.S. (4 Wall.) 277, 323 (1867)); Fletcher v. Peck, 10 U.S. (6 Cranch) 87, 138-39 (1810) (dictum) ("A bill of attainder may affect the life of an individual, or may confiscate his property, or may do both."); see also 3 STORY, supra note 18, at 210-11; TRIBE, supra note 18 , at $642-43$.

27. 3 William Blackstone, Commentaries *283-84; see also 4 id. at *31920. (1961).

28. See Communist Party v. Subversive Activities Control Bd., 367 U.S. 1, 82, 88

29. 4 ANNALS OF CONG. 934 (1794). For more recent discussions of how legislative and executive blacklists encouraging private reprisals offend the nonattainder principle, see Joint Anti-Fascist Refugee Comm. v. McGrath, 341 U.S. 123, 142-44 (1951) (Black, J., concurring); Kairys, supra note 23, at 1510-11. 
the purpose and social meaning of our ineligibility law is to stigmatize or degrade a named person - to "taint" or "stain" him, or to label him as less worthy or deserving of less respect or trust than his fellow citizens - then it should be treated like Hypothetical Two: as a bill of pains and penalties that offends the nonattainder principle. And so the Supreme Court held in landmark cases dealing with government employment (United States v. Lovett ${ }^{30}$ ) and union leadership (United States v. Brown ${ }^{31}$ ).

A law naming persons and singling them out for distinctive treatment is suspicious. Not all such laws are unconstitutional, however. For example, a law giving Akhil Reed Amar a special benefit would probably not violate the nonattainder principle, although at some point special privilege laws could raise questions under the Title of Nobility Clauses and more general equal protection and republican government principles. $^{32}$ Special privilege laws - private bills in the immigration context, targeted tax benefits in omnibus revenue bills, and so on - are commonplace. ${ }^{33}$ But as the landmark Chadha case makes clear, a law singling out Jagdish Chadha for disfavored immigration treatment is very different from a law singling him out for favored immigration treatment. ${ }^{34}$ As Justice Powell's Chadha concurrence explained, the anti-Jagdish Chadha action reflected in Congress's legislative veto was

30. 328 U.S. 303 (1946) (invalidating, on Attainder Clause grounds, a congressional act disqualifying three named suspected subversives from federal employment).

31. 381 U.S. 437 (1965) (invalidating, on Attainder Clause grounds, a congressional act targeted at Communist Party by name and disqualifying members of named party from union leadership positions). These cases build on landmark Attainder Clause cases a century earlier, invalidating laws that rendered certain described (but not named) former Confederate sympathizers ineligible to occupy certain professions of honor. See Cummings v. Missouri, 71 U.S. (4 Wall.) 277 (1867); Ex parte Garland, 71 U.S. (4 Wall.) 333 (1867). Garland was only the third case in U.S. history in which the Supreme Court held an act of Congress unconstitutional. Marbury and Dred Scott were the first and second. See Marbury v. Madison, 5 U.S. (1 Cranch) 137 (1803); Scott v. Sandford, 60 U.S. (19 How.) 393 (1857).

32. See U.S. CONST. art. I, $\S 9$, cl. 8 (prohibiting federal titles of nobility); U.S. CONST. art. I $\S 10$, cl. 1 (prohibiting state titles of nobility); U.S. CoNST. art. IV, $\S 4$ (Republican Government Clause); U.S. CoNST. amend. XIV, § 1 (Equal Protection Clause). For a general discussion of the equality ideal underlying Republican Government, see Akhil Reed Amar, The Central Meaning of Republican Government: Popular Sovereignty, Majority Rule, and the Denominator Problem, 65 U. Colo. L. REv. 749 (1994).

33. Especially, it seems, in New Orleans. See, e.g., City of New Orleans v. Dukes, 427 U.S. 297 (1976) (special privileges for selected vendors); Kotch v. Board of River Port Pilot Commrs., 330 U.S. 552 (1947) (nepotism in river boat pilot licensing); The Slaughter-House Cases, 83 U.S. (16 Wall.) 36 (1872) (butcher monopoly).

34. INS v. Chadha, 462 U.S. 919, 966 n.9 (1983) (Powell, J., concurring). 
indeed a violation of the nonattainder principle..$^{35}$ Justice Powell's analysis holds even if we see deportation suspension and government employment as "privileges" rather than "rights." When the legislature singles out named persons for ineligibility for a generally available "privilege," courts should be very suspicious.

Perhaps not all such ineligibility laws are always unconstitutional. In some cases, perhaps a particularly good reason exists for a narrow, limited, and precisely targeted ineligibility. But the logic here is not that the nonattainder right is sometimes outweighed; rather, it is that the right is sometimes not violated. We have gone beyond the narrow nonattainder rule (Hypothetical One) to the broader nonattainder principle that the rule exemplifies (Hypothetical Two, for example). This broader principle focuses on whether the legislatively prescribed ineligibility is indeed a kind of pain or penalty or badge of opprobrium. ${ }^{36}$ If not - if no real legislative animus exists - a narrow ineligibility might pass muster.

As the union leadership example makes clear, ineligibility for benefits or privileges in the private sector - a kind of petty outlawry can also offend the nonattainder principle.

Hypothetical Five. "The Amar Clan Ineligibility Law. Akhil Reed Amar and his forty-nine closest relatives shall be ineligible to be gov-

35. Chadha, 462 U.S. at 962 (Powell, J., concurring). The Chadha majority did not reach the attainder issue but did quote Attorney General Robert Jackson's condemnation of a bill that would have required a single named person's deportation as "an historical departure from an unbroken American practice and tradition." 462 U.S. at 935 n.8 (majority opinion). Sitting on the Ninth Circuit in 1980, then-Judge Kennedy who would later assume Justice Powell's seat on the Supreme Court - invalidated the Chadha legislative veto on general separation of powers grounds, and noted that the treatment Jagdish Chadha received also raised "serious bill of attainder and equal protection problems." INS v. Chadha, 634 F.2d 408, 435 \& n. 42 (9th Cir. 1980).

36. See generally Dent v. West Virginia, 129 U.S. 114, 128 (1889); Hawker v. New York, 170 U.S. 189 (1898); United States v. Brown, 381 U.S. 437, 453-54 (1965); Nixon v. Administrator of Gen. Servs., 433 U.S. 425 (1977). In Dent and Hawker, the Court upheld the power of the state to define qualifications reasonably related to professional fitness. In neither case did the state single persons out for their political activity or limit their political rights. In Brown, the law did target a reviled political group the Communist Party - by name, and the Court viewed the law far more skeptically and invalidated it. In Nixon, the Court held that a law that singled out Richard Nixon by name for distinctive treatment responded reasonably to unique issues raised by his Presidency, and that this distinctive treatment was not penal, punitive, or dishonoring, as evidenced by a willingness to compensate Nixon for any property taken from him. Note also that attainder principles may be at their low ebb where Presidents are concerned, in light of certain judicial powers vested in Congress in various impeachment clauses. Even after he left office, Richard Nixon was probably subject to impeachment and disqualification from future officeholding; and Congress perhaps could legislate to prevent destruction of any papers that might relate to impeachability. 
ernment employees or union leaders." This law simply compounds the wrong of Hypothetical Four. It effectively attaints - tars, stains - fifty persons rather than one; it is fifty attainders rolled into a single bill. And the fact that it does not quite mention forty-nine by name does not save it. ${ }^{37}$ It targets specific persons for who they are. It penalizes them for their status, not their conduct. ${ }^{38}$ It unconstitutionally treats persons as having "corrupt blood."

Hypothetical Six. "The Indian-American Ineligibility Law. All Americans of East Indian descent shall be ineligible to be government employees or union leaders." This law offends a deep principle of the Attainder Clause and shows how the Clause is indeed a prototype of the Equal Protection Clause. If Colorado may not attaint fifty persons on the basis of their status, neither may it attaint fifty thousand. ${ }^{39}$ Here too the greater numbers merely compound the constitutional wrong.

We can now see why pre-Bolling civil rights crusaders reached for the Article I, Section 9 Attainder Clause as a powerful weapon against federal discrimination against blacks. ${ }^{40}$ On this theory, even under the original Constitution, Congress would have been barred from adopting a statute captioned "An Act to Degrade and Humiliate Free Blacks in the District of Columbia." 41 And, of course, that is what Jim Crow in Washington, D.C., was in 1954. Supporters of the old order denied this,

37. See 8 Will. 3, ch. 5 (1696) (attainder by description of "such persons" involved in an assassination plot); 26 Hen. 8, ch. 6 (priv.) (1534) (attainting "all suche persons" who confederated with Thomas Fitzgerald, the Earl of Kildare); Brown, 381 U.S. at 461 (invalidating as a bill of attainder a law that inflicted deprivation upon the membership of the Communist Party rather than upon a list of named individuals); see also Cummings v. Missouri, 71 U.S. (4 Wall.) 277, 323 (1869) (invalidating, on Attainder Clause grounds, a law that targeted former Confederate sympathizers, but not by name); Ex parte Garland, 71 U.S. (4 Wall.) 333 (1867) (similar).

38. Cummings, Garland, and Brown all involved laws that penalized prior political activity or sympathy; these ex post facto penalties were thus status-based at the time of enactment, with legislators heaping disabilities on a fixed class.

39. If a law that says "all members of the Amar Clan are deemed criminals" is an impermissible attainder, so is one that says "all members of the Indian race are deemed criminal." See Brown, 381 U.S. at 461 (invalidating, on Attainder Clause grounds, a law that punished the Communist Party by name - a party with thousands of members - and noting that it "was not uncommon for English acts of attainder to inflict their deprivations upon relatively large groups of people, sometimes by description rather than name"). Cummings and Garland, of course, also invalidated attainder laws penalizing vast groups of former Confederate sympathizers. See Cummings, 71 U.S. (4 Wall.) at 323 (noting that a bill of attainder "may be directed against a whole class").

40. See supra text accompanying note 16 .

41. Cf. 4 BLACKSTONE, supra note 27 , at $* 381$ ("He is then called attaint, attinctus, stained or blackened. He is no longer of any credit or reputation; he cannot be a witness in any court .....") (emphasis altered). Under the infamous Black Codes of the 1860 s, blacks were indeed barred from testifying in court because of their black and "degraded" character. 
but the true social meaning of these laws was apparent to honest observers in 1954, if not in $1896 .{ }^{42}$ And the key question about segregation - is it really equal, or does it create two classes, one superior and one inferior? - is roughly the same whether we employ the nonattainder principle or the equal protection principle.

It might be thought that this argument proves too much. Under this account of the true spirit of the nonattainder principle, wasn't slavery unconstitutional from the outset? For surely punishing a person - by effective life imprisonment - merely because he was born to a slave mother seems an obvious status-based punishment. Yet surely slavery was constitutional in 1789 , wasn't it?

There are two responses here. The first, technical response is to distinguish between slaves and all free persons, including free blacks. Slaves were by definition deemed outside the constitutional compact beyond the Constitution's protections. Constitutionally speaking, they were akin to outlaws who indeed could be treated as wild beasts. But as Justice Curtis proved decisively in his Dred Scott dissent, ${ }^{43}$ free blacks were, from the Founding on, very much part of "We the People." They were citizens in free states where at times they voted, served in militias, held offices of honor, and so on.

The second, more candid response is that slavery was inconsistent with the spirit of the Attainder Clause - and with the spirit of many other provisions too, from due process of law to republican government. But these principles were implicitly limited by the Constitution's tacit approval of slavery in other clauses: the reference to "other" persons in the Article I Apportionment Clause, the Article IV Fugitive Slave Clause, and so on..$^{44}$ In the long run, Americans could not live with these contradictory premises - with a country and Constitution halfslave and half-free. And so after the Civil War, the Constitution worked itself pure with amendments that abolished slavery and reconfirmed the truest meaning of the freedom principles embodied in the Attainder, Due Process, Republican Government, and other Clauses.

What about women? From the Founding on, they too were subject to status-based, legislatively imposed disabilities of all sorts - legal ineligibility to act as lawyers, for example. Why didn't these disabilities violate the nonattainder principle? The nonanachronistic answer is that

42. See Charles L. Black, Jr., The Lawfulness of the Segregation Decisions, 69 YALE L.J. 421 (1960).

43. See Scott v. Sandford, 60 U.S. (19 How.) 393, $572-73$ (1857) (Curtis, J., dissenting).

44. See generally Raymond T. Diamond, No Call to Glory: Thurgood Marshall's Thesis on the Intent of a Pro-Slavery Constitution, 42 VAND. L. REv. 93 (1989). 
earlier generations (of men at least) would have indignantly denied that the purpose and social meaning of these laws was to degrade, oppress, abuse, humiliate, or stigmatize on the basis of status. These laws reflected not hostility or revulsion towards women, but respect for their separate, equal - indeed noble! - but different sphere. These laws did not seek to make women unequal; they simply recognized God-given difference. Such was, in Justice Bradley's confident phrase, "the law of the Creator." ${ }^{45}$ Today, of course, we know better, ${ }^{46}$ and modern courts have indeed invalidated legislatively imposed, status-based disabilities heaped upon women. Although modern courts have invalidated these laws under the banner of equal protection, some of the work could well have been done under the nonattainder principle.

Hypothetical Seven. "The Queer Ineligibility Law. No person of homosexual or bisexual orientation shall be eligible to be a governmental employee or a union leader." If Hypothetical Six violates the nonattainder principle, so does Hypothetical Seven, and for the same reason: the statute impermissibly singles out persons for disfavored treatment based on their status. ${ }^{47}$

Note how this law targets persons for who they are, not for what they do. Whether one's sexual "orientation" is fixed by genes, or is developed in childhood, or is even more plastic, ${ }^{48}$ "orientation" is a mat-

45. Bradwell v. Illinois, 83 U.S. (16 Wall.) 130, 141 (1873) (Bradley, J., concurring).

46. See, e.g., Frontiero v. Richardson, 411 U.S. 677, 684-85 (1973) (plurality opinion).

47. It might be argued that these two Hypotheticals are different because a person cannot easily hide the fact that she is Indian American, but she can hide the fact that she is queer. But this argument flies in the face of Cummings, Garland, and Brown. Whether a person is a former Confederate or Communist sympathizer is not etched on his face. Ex-rebs, ex-Commies, and queers can all try to "pass." Indeed, the very ability to hide one's heart or one's past can create a special measure of social anxiety about the hidden "enemy within" - a fifth column of body-snatching pod people who could be anywhere, even next door. See also supra note 37 (discussing English attainders by description in situations where attainder targets might be able to "pass").

The ability of gays to "pass" and "hide" suggests that they are not quite like blacks, who help define the paradigm case for Equal Protection Clause analysis. $C f$. Frontiero, 411 U.S. at 686 (plurality opinion) (stressing "the high visibility of the sex characteristic" to justify heightened equal protection scrutiny of sex discrimination). But under the Attainder Clause, the paradigm cases in the Supreme Court have indeed involved groups that can "pass" and "hide." So, here we see the special aptness of the Attainder Clause in thinking about the plight of queers. For a sensitive analysis of visibility and the gay closet, see Kenji Yoshino, Suspect Symbols: The Literary Argument for Heightened Scrutiny for Gays, 96 ColuM. L. REv. (forthcoming Nov. 1996).

48. See Janet E. Halley, Sexual Orientation and the Politics of Biology: A Critique of the Argument from Immutability, 46 STAN. L. REV. 503 (1994); Janet E. Halley, The Politics of the Closet: Towards Equal Protection for Gay, Lesbian, and Bisexual Identity, 36 UCLA L. REv. 915 (1989) [hereinafter Halley, Closet]. 
ter of one's inner life and not merely one's outer conduct. ${ }^{49}$ Orientation encompasses desires, fantasies, thoughts, urges, and drives that one often cannot prevent or control - even if one can resist these impulses in one's external behavior. A bedrock tenet of Anglo-American law is that punishment can occur only after offending conduct. It cannot be a crime simply to be, or merely to think or feel. ${ }^{50}$ We do not punish or publicly stigmatize a person simply because he has "corrupt blood" or impure thoughts ${ }^{51}$ - because he has an involuntary erection or because she feels wet inside. ${ }^{52}$ Once a person has violated a legitimate criminal law by his conduct, his intent and predispositions may be relevant to punishment and deterrence. But predisposition alone can never suffice. Our system does not tolerate a scheme of zero strikes and you're out or zero strikes if you're "out."

And so even if some forms of sexual conduct may be criminalized - anal sexual intercourse, for example ${ }^{53}$ - mere sexual orientation may not be. No clause makes this more clear than the Attainder Clause: it cannot be a crime simply to be who you are..$^{54}$

49. But cf. infra note 124 .

50. See Robinson v. California, 370 U.S. 660 (1962) (holding that addiction itself - as opposed to drug use - cannot be made a crime).

51. To the extent that orientation derives from thoughts, these thoughts - even (or especially) if consciously summoned up or expressed to others - also implicate First Amendment protections. See Halley, Closet, supra note 48, at 966-76; $c f$. Cummings v. Missouri, 71 U.S. (4 Wall.) 277, 318 (1867) (registering special concern under the Attainder Clause about a loyalty oath "directed not merely against overt and visible acts of hostility to the government, but ... to . . . words, desires, and sympathies, also").

52. I use blunt language here to highlight the innerness and the embodied quality of some aspects of sexuality. Surely, the law does not belong in this place, and the legislature may not condemn a person's very body as morally tainted.

53. We shall return to this issue later.

54. Another closely related constitutional provision, the Treason Clause, prevents punishing political opponents for their mere thoughts - imagining the President's death, for example - and instead requires proof of overt, willful acts of aggression against one's countrymen. See U.S. CoNST. art. III, § 3. On the historical linkage between attainder and treason, see United States v. Brown, 381 U.S. 437, 441, 453 (1965); see also William T. Mayton, Seditious Libel and the Lost Guarantee of a Freedom of Expression, 84 ColuM. L. REv. 91, 97-108 (1984) (discussing Treason Clause's rejection of English laws punishing "constructive treason" of "imagining" or "compassing" the King's death). The linkage between the Treason Clause and the Attainder Clause is not merely historical and structural, but textual too: "no Attainder of Treason shall work Corruption of Blood." U.S. CoNST. art. III, § 3. For a thoughtful discussion, see Max E. Stier, Note, Corruption of Blood and Equal Protection: Why the Sins of the Parents Should Not Matter, 44 STAN. L. REV. 727 (1992).

There is an obvious analogy between unorthodox religious and political thoughts that outraged the Establishment 250 years ago and heretical sexual fantasies that outrage the Orthodox today - "compassing" the death of traditional sex roles and the Heterosexual Order. 
Hypothetical Eight. "The Queer Discrimination Amendment. No person of homosexual or bisexual orientation shall be eligible to secure a local ordinance or state law prohibiting public or private discrimination on the basis of sexual orientation." For our purposes, this law is really no different from Hypothetical Seven. In both cases, queers are declared ineligible for things that everyone else is eligible for. The only difference is the form of ineligibility. In Hypothetical Seven it was public and private employment, and here it is legislation prohibiting public and private discrimination.

There may be no substantive constitutional right either to certain jobs or to certain anti-discrimination laws; but there is an equality right to get the same benefits that one's fellow citizens can get. Under the nonattainder principle, there is a right not to be singled out by name in a law that, metaphorically speaking, paints one's private parts red. ${ }^{55}$

Attainders are both intensely personal and obviously political; and the intertwining of the personal and the political is of course an important insight of feminists and gay rights advocates. My exposition has featured intensely personal Hypotheticals precisely to highlight the personal and private affront of a public law that names and shames. (You are invited to substitute your own name to try to imagine what a law like Hypothetical Eight might feel like to those named and targeted by it.)

Gay rights advocates also have tried to suggest that, in queer lives, equality concerns, issues of bodily integrity and privacy, and the rights of thought and expression tightly intertwine ${ }^{56}$ But constitutional litigation tends to pry these apart, pressing litigants to bend their pleas into either an equal protection formula, a substantive due process argument, or a First Amendment claim. The text, history, and sociology of the Attainder Clause, by contrast, may liberate litigants to reunite these intertwined concerns: attainders are all about equality, bodies, and expression. ${ }^{57}$ And so for some problems - like Hypothetical Eight - the

55. On the ways in which such government-painted bull's-eyes can invite private punishment, see supra note 29 and accompanying text. $C f$. Kendall Thomas, Beyond the Privacy Principle, 92 Colum. L. Rev. 1431 (1992) (arguing that the coded social meaning of Bowers v. Hardwick, 478 U.S. 186 (1986), was to declare open season on, and invite private violence against, queers). Gays are, apparently, disproportionately victims of violent bashings, whose embodied goriness recalls that of historic attainders. See supra note 18. For a rich discussion of the ways in which Nazi laws in effect painted pink triangles on gays, see Yoshino, supra note 47. (1993).

56. See Nan D. Hunter, Identity, Speech, and Equality, 79 VA. L. REV. 1695

57. And about dishonor, too. $C f$. Cummings v. Missouri, 71 U.S. (4 Wall.) 277, 320 (1866) (stressing that "liberty" encompasses "freedom from outrage on the feelings as well as restraints on the person"). 
Attainder Clause may be a particularly apt tool of analysis. ${ }^{58}$

Of course, Hypothetical Eight is not really hypothetical. It is essentially Colorado's Amendment $2 .{ }^{59}$ Shorn of words unnecessary for present purposes, Amendment 2 reads as follows:

No Protected Status Based on Homosexual, Lesbian, or Bisexual Orientation. [No state agency or municipality shall] enforce any ... policy whereby homosexual, lesbian, or bisexual orientation ... shall ... entitle any person [so oriented] to [a] claim of [orientation] discrimination.

These words are unconstitutional on their face. They are, as Justice Kennedy wrote, a violation of constitutional principles "in the most literal sense." 60 It is as if Colorado passed an Amendment captioned: "An Amendment to Violate the Equal Protection and Nonattainder Principles." Or, to take another real-life example, these words recall the haplessly worded policy once adopted by the Los Angeles International Airport banning all "First Amendment activities" - a nobrainer invalidated by the Supreme Court 9-0 in 1987 in an eight-page opinion authored by Justice O'Connor. ${ }^{61}$

To be sure, the clearly unconstitutional thread of Amendment 2 was entangled in all sorts of other knotty verbiage. But the Colorado Supreme Court showed no inclination to unravel this mess or rewrite

58. Not surprisingly, the Attainder Clause has been raised in various recent lower court cases involving gay rights. See, e.g., Richenberg v. Perry, 909 F. Supp. 1303, 1314 (D. Neb. 1995); Walmer v. United States Dept. of Defense, 835 F. Supp. 1307, 1314-15 (D. Kan. 1993), affd., 52 F.3d 851, 855 (10th Cir. 1995) cert. denied, 116 S. Ct. 474 (1995); Meinhold v. United States Dept. of Defense, 808 F. Supp. 1453, 1455 (C.D. Cal. 1992), modified and vacated in part, 34 F.3d 1469 (9th Cir. 1994). In Walmer and Richenberg, the courts rejected Attainder Clause claims. In Meinhold, the court issued a preliminary injunction against the U.S. Navy on the ground that mandatory discharge of gay service members on the basis of their "sexual status" violated the Attainder Clause. In subsequent proceedings, however, the Attainder Clause claim apparently dropped out of the case. Of course, my claim here is not that the Clause is some magic bullet that will always win for gays, but that it is, in some cases, an especially apt tool.

59. Amendment 2 was adopted by popular referendum, but this legislative action should be treated no differently from other legislative action under the Attainder Clause - or its companion, the Ex Post Facto Clause, for that matter. See TRIBE, supra note 18 , at $647 \mathrm{n} .27,658-59$. Given that some of the historical and structural concerns about "trial by legislature" are that such trials might reflect overheated popular passions trials by mob - it would be odd indeed if the Clause did not apply directly to the legislative acts of the populace. See Nixon v. Administrator of Gen. Servs., 433 U.S. 425, 480 \& n. 45 (1977); United States v. Brown, 381 U.S. 437, 444 (1965); 3 STORY, supra note 18, at 210-11. In fact, the Court in its first major Attainder Clause case struck down a state constitutional provision that had been ratified by a superheated popular vote. See Cummings, 71 U.S. (4 Wall.) at 322-23.

60. Romer v. Evans, 116 S. Ct. 1620, 1628 (1996).

61. See Board of Airport Commr. v. Jews for Jesus, Inc., 482 U.S. 569 (1987). 
the thing - severing words here or adding phrases there. And how to rewrite it? Should judges have extended its ban to heteros seeking antidiscrimination protection, thus invalidating local sexual orientation laws in toto ${ }^{62}$ Or should judges have let these ordinances stand while making it clear that gays and bis should have only the same orientation discrimination rights as straights but no more ${ }^{63}$ Remember also that we are dealing not with a mere statute but with a state constitutional amendment explicitly designed to limit all branches of the Colorado government, including its courts. By rewriting Amendment 2 to protect gays and bis as such, Colorado courts would be doing precisely what Amendment 2 forbids. ${ }^{64}$ More generally, it is dangerous enough that state judges can "construe" state constitutions; should they also have the power to rewrite them? Thus, the Colorado Supreme Court rightly held that the sexual orientation language was not severable from the rest of Amendment 2.65

Even more important, however, is that once judges find the rotten core of this law, they should throw the whole thing out as tainted. ${ }^{66}$ The unconstitutionality of naming some persons for disfavored treatment is visible in the very caption of Amendment 2. A statute that, say, used the word "nigger" should not be entitled to ordinary judicial deference. If the purpose of the Colorado electorate was so facially unconstitutional in so many of its words, the other words should fall too. The obvious animus of the part infects the whole.

\section{IV.}

In light of this line of analysis, we finally must consider two questions. First, is this really the Romer majority's theory? Second, if it is, what are the limiting principles of this theory, and how does it stand up to Justice Scalia's arguments in dissent?

We first turn to Justice Kennedy's majority opinion. It is short and sweet, with noble words and no footnotes. By modern standards, it is relatively free of formulaic doctrinal jargon.$^{67}$ More than most opinions, it is written for fellow citizens, and avoids intricate jousting and pointed

62. With this approach, a city community college might have been free to adopt an affirmative action plan for gays. See supra note 9.

63. With this approach, a city college could not discriminate against straights; but it could not discriminate against queers either.

64. For a general treatment of this problem, see Evan H. Caminker, Note, A NormBased Remedial Model for Underinclusive Statutes, 95 YALE L.J. 1185 (1986).

65. See Evans v. Romer, 882 P.2d 1335, 1349 (Colo. 1994).

66. See generally Caminker, supra note 64.

67. See generally Robert F. Nagel, The Formulaic Constitution, $84 \mathrm{MICH}$. L. REV. 165 (1985). 
back-and-forth exchanges with the dissenting Justices. In light of all this, we must read Justice Kennedy's opinion with special care, to tease as much meaning as possible out of his words. When we do, we see that there is a clear, strong, unbroken analytic and rhetorical thread that runs from start to finish in his opinion, and that this thread holds against the dissent's sharpness.

This is not to say that Justice Kennedy's opinion is flawless at every turn. (How many opinions are?) It is to say that Justice Kennedy's opinion reaches the right result, and for the right reason. The Court gets it. And this is all the more impressive given that the Court got so little help from the opinions below and from the parties' briefs, which went off on a very different theory and beckoned the Court towards a veritable doctrinal swamp - especially for formalists - as we saw in Part I above. ${ }^{68}$ But guided in part by a suggestive amicus brief, ${ }^{69}$ Justice Kennedy detoured around the bog and found firm, high ground.

$\mathrm{He}$ begins with the following words, quoting the great dissent in Plessy v. Ferguson: "One century ago, the first Justice Harlan admonished this Court that the Constitution 'neither knows nor tolerates classes among citizens." "70 It is a nice rhetorical touch, to be sure, especially because Romer comes down 100 years - to the week - after Plessy. But is it more? A casual or uncharitable reader might say no: "What does Plessy have to do with Romer? Plessy was a race case, and Romer is not." But in Plessy, Justice Harlan understood that the Fourteenth Amendment equality idea transcends "race" - a word not found in the Amendment. Justice Kennedy clearly understands this too. And what did Justice Harlan mean about "classes" in this quote? A critic might say that his statement was vacuous: all laws classify. But surely Justice Harlan knew that, and Justice Kennedy says exactly that later in his opinion. ${ }^{71}$ What both Harlan and Kennedy are saying, then, is that government may pass laws classifying conduct - if you do act $A$, you suffer consequence $B$ - but may not create classes among citizens on the basis of who they are rather than what they do. In this respect, race is rather like sexual orientation in Colorado, and Jim Crow is relevant to Amendment 2.

This is not the first time that Justice Kennedy has begun an opinion with Plessy. He did precisely the same thing in his 1990 dissent in

68. See supra text accompanying notes 7-10.

69. See supra note 6.

70. Romer v. Evans, 116 S. Ct. 1620, 1623 (1996) (quoting Plessy v. Ferguson, 163 U.S. 537, 559 (1896) (Harlan, J., dissenting)).

71. See infra text accompanying note 94 . 
Metro Broadcasting v. FCC..$^{72}$ And a key concern in that dissent was that, under affirmative action quotas, government would be deep in the blood-test business - with Nuremberg-like laws classifying persons by their ancestry and birth, by their status rather than their conduct. ${ }^{73}$ Elsewhere, Justice Kennedy has announced his attraction to color-blind constitutionalism, ${ }^{74}$ and his opening reference in Romer to Justice Harlan's famous color-blind dissent might seem to have far-reaching implications for the highly charged issue of affirmative action in education. Yet several of the Justices who joined Romer would probably allow colorconscious affirmative action in the context of education, ${ }^{75}$ and so it seems a stretch to say that Romer casts doubt on Bakke. ${ }^{76}$ Interestingly, an Attainder Clause analysis may help explain the puzzle. As we have seen, a bill singling out persons or classes for special privileges does not invariably run afoul of the nonattainder ideal. As Justice Powell who authored the famous Bakke opinion upholding diversity-based affirmative action in education - later noted, a private bill to allow Jagdish Chadha to stay in the United States is different from a private bill to expel Jagdish Chadha from American soil. ${ }^{77}$ Singling out for inclusion is sometimes quite different from singling out for exclusion or ostracism. ${ }^{78}$ Thus, race-conscious "welcome mats" may be different from race-conscious "No Trespassing" signs, ${ }^{79}$ especially if the purpose of such mats is to heal racial division by bringing all races together to live with and learn from one another as democratic equals. ${ }^{80}$

The final drop of meaning to be squeezed from Justice Kennedy's opening reference to Plessy is this: like Justice Harlan, he signals here that he will attend to social reality as well as legal form. Justice Harlan knew as a human being that separate was not and would not be equal, and said so as a judge. Similarly, Justice Kennedy's opinion ranges be-

72. 497 U.S. 547, 631 (1990) (Kennedy, J., dissenting).

73. See 497 U.S. at 633 n.1 (Kennedy, J., dissenting).

74. See, e.g., City of Richmond v. J.A. Croson Co., 488 U.S. 469, 518 (1989) (Kennedy, J., concurring).

75. See generally Akhil Reed Amar \& Neal Kumar Katyal, Bakke's Fate, 43 UCLA L. REV. 1745 (1996).

76. Regents of the Univ. of Cal. v. Bakke, 438 U.S. 265 (1978).

77. See INS v. Chadha, 462 U.S. 919, 966 n.9 (1983) (Powell, J., concurring).

78. On one possible view, singling out for inclusion should offend the Constitution only if it creates a privileged upper caste in violation of the spirit and sociology underlying the Title of Nobility Clauses. Sociologically, it would be stretching things to say that racial minorities who are given a leg up in educational affirmative action plans are truly an upper caste of nobility today.

79. This language is borrowed from Adarand Constructors, Inc. v. Pena, $115 \mathrm{~S}$. Ct. 2097, 2114 (1995). It is discussed in more detail in Amar \& Katyal, supra note 75.

80. This is, of course, Justice Powell's noble vision in Bakke. For much more discussion of that vision, see Amar \& Katyal, supra note 75. 
yond text and form to ponder the exclusionary social meaning beneath the surface of Amendment 2. On this deeper level, the laws at issue in both Plessy and Romer are about untouchability and uncleanness: they are not like $u s .^{81}$ In Plessy, the marker of this untouchability was seemingly trivial: blacks must ride in this car rather than that one. But Justice Harlan foresaw what bitter fruit could grow from such a seed; and with the benefit of this lesson, Justice Kennedy saw a seemingly small inequality in Romer and killed it before it could take root and spread.

After this deft opening nod to Harlan, Justice Kennedy begins to narrate the history of Amendment 2 as a response to local ordinances prohibiting discrimination based on "sexual orientation." 82 These ordinances protected all citizens. Boulder, for example, protected a person's "choice of sexual partners, i.e. bisexual, homosexual or heterosexual." 83 Denver's ordinances explicitly protected status; Justice Kennedy cites Denver's Code as “defining 'sexual orientation' as '[t]he status of an individual as to his or her heterosexuality, homosexuality, or bisexuality." "84 Amendment 2, Kennedy then adds, did not repeal these ordinances in toto, but only "to the extent they prohibit discrimination on the basis of 'homosexual, lesbian or bisexual orientation, conduct, practices or relationships." "85 The issue at hand is not, then, whether sexual orientation can be treated differently (from, say, race); but whether gays and $b i s$ can be treated differently (from straights). ${ }^{86}$

If Justice Kennedy's framing is not overwhelmingly clear from his first two paragraphs, it surely emerges in his third, where he quotes Amendment 2 in its entirety and pointedly describes the law as singling out a "named class, a class we shall refer to as homosexual persons or

81. The ideas of degradation and impurity, of stigma and uncleanness, are more obvious in the text of the Attainder Clause - with its explicit focus on "tain[t]" than in the more abstract language of the Equal Protection Clause. Of course, both Clauses, historically speaking, were tightly bound up with concerns about stigma and "corrupt" or "degraded" "blood."

82. Romer v. Evans, 116 S. Ct. 1620, 1623 (1996).

83. $116 \mathrm{~S}$. Ct. at 1623 (emphasis added) (quoting Boulder, Colo., Rev. Code $\S 12-1-1(1987))$.

84. $116 \mathrm{~S}$. Ct. at 1623 (emphasis added) (quoting Denver, Colo., Rev. MuN. CODE art. IV, § 28-92 (1991)).

85. $116 \mathrm{~S}$. Ct. at 1623 (emphasis added).

86. Cf. Gerald Gunther, Congressional Power To Curtail Federal Court Jurisdiction: An Opinionated Guide to the Ongoing Debate, 36 STAN. L. Rev. 895, 917-18 (1984) (critiquing Professor Tribe's jurisdictional gerrymandering theory, rooted in an analogy to Hunter v. Ericksen, 393 U.S. 385 (1969), as collapsing the distinction between laws that distinguish between litigants and laws that distinguish between subject matters; on Gunther's view, Congress might create a separate court for sexual orientation issues, but not for gay plaintiffs). Professor Gunther, of course, joined Professor Tribe's Romer brief. See supra note 6. 
gays and lesbians." 87 The word "class" here of course recalls Kennedy's opening quote from Harlan in Plessy; and the word "named" foreshadows its use later in the opinion and strongly hints at the attainder idea. In his "we shall refer to" clause, Justice Kennedy in effect promises to keep his eye on the disadvantaged class (gays and lesbians) and not merely on the formal classification (sexual orientation). The remainder of Kennedy's opinion redeems this promise, with its insistent and acute focus on the attainted persons themselves: gays and lesbians.

In his next two paragraphs, Justice Kennedy quickly recounts the history of Romer as a lawsuit brought by "homosexual persons" fearing discrimination "on the basis of their sexual orientation." 88 The Colorado Supreme Court had based its holding for plaintiffs in part on the distinctive issues raised by Amendment 2 as a state constitutional provision bumping up certain issues from the plane of local politics to statewide politics. ${ }^{89}$ But if Amendment 2 is unconstitutional because it singles out a named class of persons for status-based disadvantage, it does not matter whether it is a state constitution, a state statute, or a local ordinance. And so Justice Kennedy announces that his Court will "affirm the judgment, but on a rationale different from that adopted by the State Supreme Court." 90

Thus ends Part I of Kennedy's opinion. The analytic linchpin of Part II is Justice Kennedy's claim that Amendment 2 "imposes a special disability upon [homosexuals] alone" - a group he also refers to as the "targeted class." 91 In a nutshell: "Homosexuals are forbidden the safeguards that others enjoy or may seek without constraint." 92

This claim is further elaborated and explored by Justice Kennedy in Part III of his opinion. Early in that section he writes that Amendment 2 "has the peculiar property of imposing a broad and undifferentiated disability on a single named group, an exceptional and, as we shall explain, invalid form of legislation." 93 A careless or uncharitable critic might ask: What can this possibly mean? How is inability to win special heightened scrutiny in antidiscrimination laws a "broad and undifferentiated disability?" Don't many laws disadvantage one group or another? Indeed, Justice Kennedy himself explicitly admits this three

87. Romer, $116 \mathrm{~S}$. Ct. at 1623 (emphasis added).

88. $116 \mathrm{~S}$. Ct. at 1624.

89. See 116 S. Ct. at 1624 (citing Evans v. Romer, 854 P.2d 1270 (Colo. 1993)).

90. $116 \mathrm{~S}$. Ct. at 1624.

91. $116 \mathrm{~S}$. Ct. at 1626 (emphasis added); cf. supra notes 29,55 and accompanying text (discussing targets and bull's-eyes).

92. $116 \mathrm{~S}$. Ct. at 1627.

93. $116 \mathrm{~S}$. Ct. at 1627. 
sentences earlier: "most legislation classifies for one purpose or another, with resulting disadvantage to various groups or persons." 94 If this is so, a critic might ask: What is so "peculiar," "exceptional," and "invalid" about the "form" of legislation that hurts a given group?

The answer, of course, is that Amendment 2 targets a single named group. This is the key word in this key sentence, echoing Kennedy's earlier word use. And, of course, to name a person or a group by law for disadvantage is an "exceptional" and "invalid" "form" of "legislation." It is a bill of attainder.

Not all laws that name suffer this fatal flaw - only those that, in Kennedy's words, reflect "animus toward the class." 95 Thus, in his next paragraph, the Justice cites with apparent approval Kotch v. Board of River Port Pilot Commrs., ${ }^{96}$ in which the Court upheld a kind of private bill system that in effect gave certain favored persons special pilotlicensing privileges. Sometimes a personalized welcome mat may be different from a status-based "No Trespassing" sign..$^{97}$ Courts must examine designer laws to ensure that they are not "drawn for the purpose of disadvantaging the group burdened by the law." 98

In his next paragraph, Justice Kennedy reminds us of just how odd Amendment 2 is: "It identifies persons by a single trait . . . ."99 An obtuse critic might think that all laws do so, but most laws identify conduct rather than traits: if you do $A$, consequence $B$ ensues. Laws based on traits - blood type or blood lines, left-handedness or a sweet tooth, sexual orientation and so on - are different; and Amendment 2 is "unprecedented in our jurisprudence." 100

By now, of course, the point should be clear, and the remainder of Justice Kennedy's opinion drives it home cleanly. Here is a compressed version of four of his last five paragraphs:

It is not within our constitutional tradition to enact laws of this sort. ... [L]aws singling out a certain class of citizens for disfavored legal status or general hardships are rare.

... [L]aws of the kind now before us raise the inevitable inference that the disadvantage imposed is born of animosity toward the class of persons affected [ - born of] "a bare ... desire to harm a politically unpopular group."

94. $116 \mathrm{~S}$. Ct. at 1627.

95. $116 \mathrm{~S}$. Ct. at 1627 (emphasis added).

96. 330 U.S. 552 (1947).

97. See supra note 79.

98. Romer, $116 \mathrm{~S}$. Ct. at 1627 (emphasis added).

99. $116 \mathrm{~S}$. Ct. at 1628.

100. 116 S. Ct. at 1628 . 
... Amendment $2 \ldots$ is a status-based enactment[,] . . a classification of persons undertaken for its own sake ...." [C]lass legislation.. . [is] obnoxious to the prohibitions of the Fourteenth Amendment ...."

We must conclude that Amendment 2 classifies homosexuals not to further a proper legislative end but to make them unequal to everyone else. This Colorado cannot do. A State cannot so deem a class of persons a stranger to its laws. ${ }^{101}$

Finally, let us turn to the one paragraph omitted from this compressed version of Romer's coda. In this paragraph, Justice Kennedy for the first and only time - turns from his main narrative to address the dissent directly. As we shall see in more detail below, Justice Scalia waves the red flag of Bowers v. Hardwick ${ }^{102}$ and dares the Court to charge. In effect, Scalia argues that since Colorado can criminalize queer sex, surely it can take the lesser step of preventing queers from winning antidiscrimination laws. Sodomy can be made a felony, and felons can be wholly disenfranchised. And so queers cannot complain if they are treated better than this, as they surely are in Colorado.

The Court, however, makes no explicit reference to Bowers, leading Scalia to shout "Gotcha!": "The case most relevant to the issue before us today is not even mentioned in the Court's opinion." 103 But one need not cite a case to distinguish it; ${ }^{104}$ and in a deft paragraph Justice Kennedy explains how Bowers - far from being the "case most relevant" - is a case not remotely relevant. Kennedy does this through the trope of Davis v. Beason, another off-point case dredged up by the dissent:

Davis v. Beason, 133 U.S. 333 (1890), not cited by the parties but relied upon by the dissent, is not evidence that Amendment 2 is within our constitutional tradition, and any reliance upon it as authority for sustaining

101. 116 S. Ct. at 1628-29 (quoting United States Dept. of Agric. v. Moreno, 413 U.S. 528, 534 (1973); Civil Rights Cases, 109 U.S. 3, 24 (1883)). Note especially the repeated emphasis here on "status" and "class" and the rich outlawry imagery in the final sentence.

102. 478 U.S. 186 (1986).

103. Romer, 116 S. Ct. at 1631 (Scalia, J., dissenting). Elsewhere Justice Scalia accuses the Court of "ignoring [the] inconvenient precedent" of Bowers. $116 \mathrm{~S}$. Ct. at 1632 (Scalia, J., dissenting). In two other places, he notes that Bowers is "unchallenged here" and that respondents "expressly disavowed any intent" to overrule it. $116 \mathrm{~S}$. Ct. at 1629,1631 (Scalia, J., dissenting). In yet another spot, he taunts the Court for being "unwilling to join" the Bowers debate. $116 \mathrm{~S}$. Ct. at 1636 n.3 (Scalia, J., dissenting).

104. Perhaps the Romer Court did not cite Bowers because some members of the Court now deem the case an embarrassment, just as some Founders found slavery an embarrassment and omitted all explicit mention of it in the Constitution. For some Justices, perhaps even to cite Bowers would have been to "distinguish" it in a different sense: to give it undeserved distinction and respect. Or perhaps some Justices in the majority still approve of Bowers and would resist an explicitly negative "but see" citation. 
the amendment is misplaced. . . . To the extent it held that the groups designated in the statute may be deprived of the right to vote because of their status, its ruling ... [is] most doubtful ... [C]f. United States v. Brown, 381 U.S. 437 (1965) . . . To the extent Davis held that a convicted felon may be denied the right to vote, its holding is not implicated by our decision and is unexceptionable. ${ }^{105}$

Look here, Justice Kennedy is saying. There is all the difference in the world between legislative deprivations based on status and punishments based on conduct. To think otherwise is terminally silly (though Kennedy is far too polite to say so bluntly). Thus, whether or not certain forms of sexual conduct may be criminalized - a question the Court need not and therefore does not reach - mere orientation cannot be criminalized or used by law to disenfranchise or degrade. And lest anyone miss the point, the Court cites United States v. Brown, a case not cited by the parties or the courts below. The inclusion of Brown is the brainchild of the Court (as the Davis cite was Justice Scalia's idea). And what is Brown about? It is a landmark case invalidating a bill of attainder - the very case featured above in Hypothetical Four. ${ }^{106}$

\section{V.}

It remains to test this theory against Justice Scalia's dissent. The Justice describes his own dissent as "vigorous[]," 107 and it surely is that. "Derisive" might be even more accurate, given its description of the majority opinion as "hand-wringing," "terminal[ly] sill[y]," "long on emotive utterance," "ridiculous," "unheard-of," "facially absurd," "novel and extravagant," "nothing short of insulting," and "nothing short of preposterous." 108 What accounts for this tone?

Just as Justice Kennedy's first sentence gives us a helpful window onto his own thinking, Justice Scalia's first sentence is also revealing: "The Court has mistaken a Kulturkampf for a fit of spite." 109 The Kulturkampf reference reminds us of the highly charged nature of debates over gay rights - recalling similar culture wars over abortion and school prayer. And once we see this, we can see that, for Justice Scalia, this is déjà vu all over again. In 1992, Justice Kennedy co-authored the opinion of the Court in Planned Parenthood v. Casey ${ }^{110}$ upholding abortion rights, and Justice Scalia (joined by Chief Justice Rehnquist and

105. Romer, $116 \mathrm{~S}$. Ct. at 1628 (citations omitted).

106. Indeed, Brown is featured throughout the footnotes in Part III.

107. Romer, 116 S. Ct. at 1629 (Scalia, J., dissenting).

108. $116 \mathrm{~S}$. Ct. at $1630,1631,1634,1637$ (Scalia, J., dissenting).

109. $116 \mathrm{~S}$. Ct. at 1629 (Scalia, J., dissenting).

110. 505 U.S. 833 (1992). 
Justices Thomas and White) wrote a stinging dissent. That same year, Justice Kennedy authored the opinion of the Court in Lee v. Weisman ${ }^{111}$ invalidating a high school commencement prayer, and Justice Scalia (joined by the same three colleagues) wrote a stinging dissent.

It is not just that the lineups in these three cases are similar; so are the basic moves and tone of Justice Scalia's dissents. In Casey, he argued that the Justices were simply making things up: "[T]he Constitution says absolutely nothing about [abortion.]" 112 He says the same thing in Romer: "[T]he Constitution of the United States says nothing about this subject." 113 So too, Scalia's final paragraph in Romer "Today's opinion has no foundation in American constitutional law, and barely pretends to" 114 - recalls John Hart Ely's famous line on Roe: "[I]t is not constitutional law and gives almost no sense of an obligation to try to be." 115 To the extent Casey built on Roe, and Roe did not exactly build on stone, Justice Scalia had a good point in Casey. But not in Romer. Here, as we have seen, Justice Kennedy's opinion builds squarely on deep constitutional tradition and structure. Here, John Hart Ely supports Justice Kennedy's approach in the scholars' brief he co-signs. (Though nowhere cited in this brief, Ely has also authored a famous student note and an important article on - you guessed it - the Attainder Clause. ${ }^{116}$ Ely also served as a law clerk to Chief Justice Warren during the term Warren handed down the Court's landmark Attainder Clause case, United States v. Brown ${ }^{117}$ ).

Scalia's Romer dissent also echoes his Lee dissent. There too, Justice Kennedy wrote a clean, grand opinion with no footnotes and in a voice comprehensible to fellow citizens. The Justice looked beyond legal form to social substance. No one is legally obliged to attend her high school commencement, but who would want to miss it or to feel excluded by a specific prayer that emotionally invites others in, but shuts her out? ${ }^{118}$ Peer pressure is a fact of life in high school, ${ }^{119}$ and it is not fair to force some students to stand up for their rights by standing

111. 505 U.S. 577 (1992).

112. Casey, 505 U.S. at 980 (Scalia, J., dissenting).

113. Romer, 116 S. Ct. at 1629 (Scalia, J., dissenting).

114. $116 \mathrm{~S}$. Ct. at 1637 (Scalia, J., dissenting).

115. John Hart Ely, The Wages of Crying Wolf: A Comment on Roe v. Wade, 82 YALE L.J. 920, 947 (1973) (emphasis deleted) (discussing Roe v. Wade, 410 U.S. 113 (1973)).

116. See John Hart Ely, United States v. Lovett: Litigating the Separation of Powers, 10 HARV. C.R.-C.L. L. REV. 1 (1975); Note, supra note 21.

117. 381 U.S. 437 (1965).

118. See Lee v. Weisman, 505 U.S. 577, 586-95 (1992).

119. See Lee, 505 U.S. at 593-94. 
out and apart from their classmates on a day when all should stand together. "[I]n effect," if not in form, Justice Kennedy wrote in Lee, the school "required participation in a religious exercise." 120 In Romer Kennedy says that, in effect, Colorado has singled out named persons for disfavored treatment. In his dissent in Lee, Justice Scalia mocked the Court's sensitivity to broader social meaning, suggesting that a theory of "psychological coercion" was, "not to put too fine a point on it, incoherent." 121 And in Romer he opines that the Court's portrayal of Coloradans as gay-bashing is "so false as to be comical." 122 Even if Justice Scalia had a point in Lee - though I happen to think not - he has none in Romer. For as we have seen, Amendment 2 is formally flawed in a way that should be clear even to the most finicky formalist. It is flawed on its face - in its words, not just in their spirit.

What are Justice Scalia's main counterarguments? At one point he notes that all constitutional provisions disfavor those opposed to them and entrench the disadvantage, forcing opponents to scale high walls: "The Eighteenth Amendment to the Federal Constitution, for example, deprived those who drank alcohol not only of the power to alter the policy of prohibition locally or through state legislation, but even of the power to alter it through state constitutional amendment or federal legislation." 123 This is of course correct - it is the same point I made above in Part I - but it is utterly unresponsive to the unique problem of status-based laws.

Elsewhere in the opinion, Justice Scalia dangerously blurs the key constitutional difference between status and conduct. ${ }^{124} \mathrm{He}$ reads state laws prohibiting polygamy as "singl[ing] out" "those who have a polygamous 'orientation.' "125 But surely he cannot mean that these laws do or could punish mere orientation - a disposition, a hankering, an urge - without an act.

Or can he? Consider the following passage:

If it is rational to criminalize the conduct, surely it is rational to deny special favor and protection to those with a self-avowed tendency or de-

120. 505 U.S. at 594.

121. 505 U.S. at 636 (Scalia, J., dissenting).

122. Romer v. Evans, 116 S. Ct. 1620, 1633 (1996) (Scalia, J., dissenting).

123. $116 \mathrm{~S}$. Ct. at 1634-35 (Scalia, J., dissenting) (emphasis omitted).

124. Alas, he is not alone. See $116 \mathrm{~S}$. Ct. at 1632 (Scalia, J., dissenting) (citing various lower court opinions collapsing the obvious analytic distinction between homosexual orientation and homosexual conduct). For a discussion and analysis of many of these cases, see Janet E. Halley, Reasoning About Sodomy: Act and Identity in and After Bowers v. Hardwick, 79 VA. L. REv. 1721 (1993); Nan D. Hunter, Life After Hardwick, 27 HARV. C.R.-C.L. L. REV. 531 (1992).

125. Romer, 116 S. Ct. at 1635 (Scalia, J., dissenting). 
sire to engage in the conduct. Indeed, where criminal sanctions are not involved, homosexual "orientation" is an acceptable stand-in for homosexual conduct. ${ }^{126}$

This is one of the most troubling passages ever to appear in modern U.S. Reports. For starters, the word "special" in the first sentence is a cheat. The issue here is the right of gays and bis to have the same right against orientation discrimination enjoyed by heteros qua heteros. And unless all bets are off when "homosexuals" are involved, the second sentence suggests that - as a matter of general principle - orientation is an acceptable stand-in for conduct. But Scalia himself must know this is not the case, and so he qualifies his claim with the phrase "where criminal sanctions are not involved." Why? Because otherwise, to use orientation as a stand-in in a law would be an obvious bill of attainder. But the bill of attainder principle is not limited to criminal cases, as is made clear in United States v. Brown ${ }^{127}$ - the very case featured in our Hypothetical Four and highlighted by Justice Kennedy in his most direct response to Justice Scalia. This is the key case - not Bowers - and it is Scalia - not Kennedy - who fails to engage. Indeed, Scalia nowhere acknowledges the case.

And in the end, what does Justice Scalia say about Bowers? He says that it is "unassailable" - unassailable! - that states can make "homosexual conduct a crime," and so "Amendment 2 is unquestionably" - unquestionably! - "constitutional as applied to those who engage in homosexual conduct." 128

But Bowers does not remotely stand for this. For starters, even where male-male anal sexual intercourse is involved, Bowers held only that criminalization did not offend substantive due process. The Court explicitly refused to address the equal protection issues at stake. ${ }^{129}$ This refusal renders Bowers highly dubious. To borrow from Yogi Berra, "when you reach a fork in the road, take it." Either male-female anal sex can be criminalized or it cannot. If it can, how exactly are the principles of Eisenstadt $t^{130}$ and now Casey ${ }^{131}$ to be distinguished away? If it cannot, then doesn't criminalization of male-male - but not male-

126. 116 S. Ct. at 1632 (Scalia, J., dissenting).

127. 381 U.S. 437 (1965). Of course, the applicability of the attainder principle beyond formal criminal punishment was established well before Brown. Indeed, it has been a basic feature of Supreme Court case law for over a century. See supra Part III.

128. Romer, 116 S. Ct. at 1631, 1632-33 (Scalia, J., dissenting).

129. See Bowers v. Hardwick, 478 U.S. 186, 188 n.2, 196 n.8 (1986).

130. Eisenstadt v. Baird, 405 U.S. 438 (1972) (extending constitutional protection to use of contraception by unmarried couples).

131. Planned Parenthood v. Casey, 505 U.S. 833 (1992) (reaffirming Eisenstadt and reaffirming constitutional protection of abortion). 
female - sodomy constitute de jure sex discrimination, in the same way antimiscegenation laws constituted de jure race discrimination? (This is surely what stone cold logic says.) ${ }^{132}$

Even if Bowers could somehow stand as an anal sex case, what about oral sex? (Again, can male-female oral sex be criminalized? And if not, how can a ban on only male-male and female-female oral sex survive a sex discrimination challenge?) And what about petting below the waist? Or above the waist? Or kissing? Or handholding and hugging? Or saying "I love you?" Did Bowers "unquestionably" apply to all this conduct? ${ }^{133}$ Justice Scalia's analysis of Bowers is not his finest hour. Indeed, sad to say, I find it the low point of Justice Scalia's distinguished decade on the Court.

Justice Scalia makes three other big points in dissent. First, he claims that Amendment 2 "prohibits special treatment of homosexuals, and nothing more." 134 They are, for example, merely deprived of the ability to get a "special" law requiring insurance companies to ignore special health risks "associated with homosexuality (if there are any)" in setting premiums. ${ }^{135}$ But since heteros can get such laws qua heteros, what is at stake is equal treatment, not special favoritism.

Second, Justice Scalia suggests that the inequality imposed forcing gays and bis to win their rights statewide while heteros can win locally - is a justified reaction to queers' special clout as a "politically powerful minority." 136 They are organized; they "reside in disproportionate numbers in certain communities"; they "have high disposable income"; they "possess political power much greater than their numbers." 137 But much the same could be said - and in some times and places has been said - of Jews. ${ }^{138}$ Surely Justice Scalia would not allow Colorado to handicap Jews in elections. Footnote four of Carolene Products ${ }^{139}$ has been turned on its head; discreteness and insularity are now occasions for legally imposed disabilities. (Recall also that gays

132. See supra note 7.

133. See Patricia A. Cain, Litigating for Lesbian and Gay Rights: A Legal History, 79 VA. L. Rev. 1551, 1624-25, 1632-34 (1993); Halley, Closet, supra note 48, at 949.

134. Romer v. Evans, 116 S. Ct. 1620, 1630 (1996) (Scalia, J., dissenting).

135. 116 S. Ct. at 1630 (Scalia, J., dissenting).

136. 116 S. Ct. at 1629 (Scalia, J., dissenting).

137. 116 S. Ct. at 1634 (Scalia, J., dissenting).

138. Cf. Yoshino, supra note 47 (discussing Nazi yellow stars for Jews and pink triangles for gays).

139. United States v. Carolene Prods. Co., 304 U.S. 144, 152 n.4 (1938) (suggesting special judicial sensitivity to protect discrete and insular minorities against prejudice). For a discussion of the ways in which gays are both discrete and insular and yet also diffuse and anonymous, see Hunter, supra note 124, at 548; Yoshino, supra note 47. 
sought only the benefit of equal discrimination laws that protected heteros too.) More generally, do we really trust government to "handicap" elections? Incumbents have too much name recognition, so can Colorado keep them off the ballot, forcing voters to write them in? The Supreme Court said no in last year's term limits case. ${ }^{140}$ Cities are more organized, so can Colorado try to reapportion its legislature to offset this advantage by deviating from population equality? The Supreme Court said no in Reynolds v. Sims. ${ }^{141}$ Even if Colorado thinks that Republicans win too much because they are fatcats - or that Democrats win too much because the media is biased - Colorado cannot single out a party by name for disfavored treatment. Even the Communist Party. That, once again, is the holding of United States v. Brown. ${ }^{142}$

Finally, Justice Scalia offers two hypotheticals that probe the limits of the majority's suspicion of status-based laws. One derives from the Murgia ${ }^{143}$ case, which upheld "a mandatory retirement age of 50 for police officers." 144 From one perspective, this law might seem statusbased: one cannot change the fact - the "trait" or "status" - of being over fifty. But from another, more sociological perspective, this law hardly singles out. Everyone, God willing, will someday reach this age and thus be subject to the disadvantage created by the law. It is hard to see how this law reflects revulsion or untouchability, a key sociological concern of both the Attainder and Equal Protection Clauses. So, even if courts look at the law with initial suspicion, it should pass muster easily. Justice Scalia's other example is a hypothetical "state law prohibiting the award of municipal contracts to relatives of mayors or city councilmen." 145 But once again, behind a veil of ignorance, this is a law that could apply to many persons in the future if their relatives happen to win office. Sociologically, no comparably thick veil insulates us from awareness of our sexual orientation. We are not all equally likely to wake up tomorrow and feel gay. Where the veil of ignorance is so thin, courts should be more suspicious. If a law prohibited Justice Scalia's relatives from serving as Court employees - while saying nothing about relatives of the other Justices - the nonattainder principle might

140. See U.S. Term Limits, Inc. v. Thornton, 115 S. Ct. 1842, 1860-71 (1995).

141. 377 U.S. 533 (1964).

142. 381 U.S. 437 (1965). curiam).

143. Massachusetts Bd. of Retirement v. Murgia, 427 U.S. 307 (1976) (per

144. Romer v. Evans, 116 S. Ct. 1620, 1632 (Scalia, J., dissenting). It is a rather striking coincidence that the Garland dissenters appealed to a remarkably similar hypothetical. See Ex parte Garland, 71 U.S. (4 Wall.) 333, 395-96 (1867) (Miller, J., dissenting) (age limit for judges not unconstitutional).

145. Romer, 116 S. Ct. at 1631 (Scalia, J., dissenting). 
well be implicated. This kind of "corruption of the blood" of relatives of a named person or class might raise the specter of animus and require careful judicial scrutiny. And if Justice Scalia sought a focused analysis of the difference between legitimate conflict-of-interest laws and illegitimate attainders, he need have looked no further than - you guessed it - United States v. Brown, which discusses this very issue at length. ${ }^{146}$

In the end, it is hard to offer a charitable interpretation of a dissent that is so, well, uncharitable. Justice Scalia's shrill tone, his overconfidence, his lapses of logic, his overreading of troubling cases like Bowers, and his resurrection of long-discredited cases like Davis ${ }^{147}$ lead one to want to wisecrack: at least he didn't cite Dred Scott with approval. But this impulse should be resisted. Justice Scalia is a jurist of extraordinary talent and principle, and so when he goes so wrong in Romer, we must wonder whether there is something in the issue of homosexuality that unsettles and unnerves, and causes many to forget their better natures. Perhaps there is something about this issue that leads good and smart people - in Colorado and on the Court - to say uncharacteristically bad and dumb things. ${ }^{148}$ If so, this may be one of the best reasons to think that the Court majority got it right after all.

146. See Brown, 381 U.S. at 453-55 (distinguishing conflict of interest laws that "condemn all men" from attainders that single out specific, named group for suspicion). I suggest that Brown articulates a veil-of-ignorance conception of sorts. For a nice discussion of how a veil-of-ignorance approach may help solve some tough equal protection issues, see Deborah Jones Merritt, Communicable Disease and Constitutional Law: Controlling AIDS, 61 N.Y.U. L. REv. 739 (1986).

Brown also suggests that political disabilities, and disabilities imposed because of political activities, are more likely to be seen as attainders. See 381 U.S. at 453-54. In this respect, First Amendment and equal protection concerns converge; and as Janet Halley has noted, courts should be especially attentive to this convergence in the area of gay rights. See Halley, Closet, supra note 48, at 968-76; see also Hunter, supra note 56. In Romer, Amendment 2 imposed a political disability - cutting off gays' and bis' political remedies at the local level - in response to their political visibility and success in Denver, Aspen, and Boulder. Justice Kennedy signals his sensitivity to this by citing - alongside Brown - United States v. Robel, 389 U.S. 258 (1967), in which a federal law targeting communists was invalidated on First Amendment grounds. See Romer, $116 \mathrm{~S}$. Ct. at 1628.

Historically, of course, the Equal Protection Clause had nothing to do with voting and other "political" rights. The Clause was about nonpolitical "civil" rights of "persons" (paradigmatically aliens) rather than "citizens." See Amar, supra note 32, at 754 \& n.18. And so here too the history of the Attainder Clause is especially apt in Romer.

147. Davis v. Beason, 133 U.S. 133 (1870), held that those who advocated polygamy could be disenfranchised.

148. For a similar observation about the nasty tone of Bowers itself, see MARY ANN Glendon, Rights Talk: The IMPOVERishment of Political Discourse 153-54 (1991); see also supra text accompanying notes 129-32 (criticizing Bowers's 
VI.

Since we began our journey with cutting words from Justice Scalia, it is only fitting that we end by returning to these words. Justice Scalia identifies the Court's principle - which he goes on to describe as "terminal silliness" - as follows: "[O]ne who is accorded equal treatment under the laws, but cannot as readily as others obtain preferential treatment under the laws, has been denied equal protection of the laws." 149

The first reference to "equal treatment" is an obvious cheat. The question at hand is whether the treatment truly is equal, and this sort of question-begging will not do. Consider next the phrase "preferential treatment." This, too, is a cheat - doubly. First, it trades on the idea that since no one should have preferential treatment, those denied it cannot justly complain. Sometimes this is true. If the legislature passed a law that "Akhil Reed Amar shall be ineligible for a title of nobility," the concrete constitutional harm - singling a person out by name would be blunted by the fact that no real inequality would exist. No one under our Constitution is eligible for a title of nobility: that is the rule of Article I, Sections 9 and 10. But if the preferential treatment is something some others can get - "Akhil Reed Amar shall be ineligible for a private immigration bill or a suspension of deportation" - then the Constitution is violated. Just ask Jagdish Chadha. Second, Amendment 2 on its face rendered queers ineligible not just for preferential treatment, but for plain-vanilla, garden-variety antidiscrimination laws laws that, for example, protect heteros from being discriminated against as heteros.

And so, properly recast, Justice Scalia's sentence boils down to this: "[O]ne who . . . cannot as readily as others obtain [certain rights and privileges] under the laws, has been denied equal protection of the laws." To state this principle is to see not its terminal silliness, but its powerful logic and simple justice.

logic and its analytically indefensible refusal to address the equal protection dilemma its approach creates).

149. Romer, 116 S. Ct. at 1630 (Scalia, J., dissenting). 